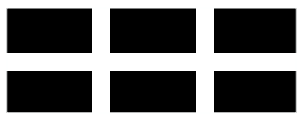

ThE WiLliam DAVIDSON InSTITUTE AT THE UNIVERSITY OF MICHIGAN BUSINESS SCHOOL

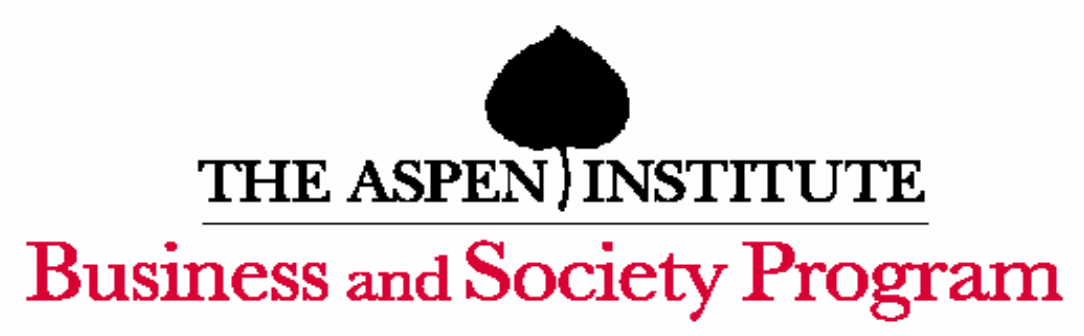

Family Control and the Rent-Seeking Society

\author{
By: Randall Morck and Bernard Yeung
}

William Davidson Institute Working Paper Number 585

June 2003 
First Draft: January $22^{\text {nd }} 2002$

This Draft: February $12^{\text {th }} 2003$

Very Preliminary, Comments Welcome

\title{
Family Control and the Rent-Seeking Society
}

\author{
Randall Morck* and Bernard Yeung**
}

\footnotetext{
* Stephen A. Jarislowsky Distinguished Professor of Finance, School of Business, University of Alberta, Edmonton, Alberta, Canada, T6G 2R6.Tel: (780) 492-5683. E-mail randall.morck@ualberta.ca; Research Associate, National Bureau of Economic Research, 1050 Massachusetts Avenue, Cambridge, MA 02138 USA.

** Abraham Krasnoff Professor of International Business and Professor of Economics, Stern School of Business, New York University, New York, NY 10012. Tel: (212) 998-0425. Fax: (212) 995-4221. E-mail byeung@stern.nyu.edu.

We are grateful for helpful suggestions by Raffi Amit, Ramon Casadesus-Masanell, Art Durnev, Curtis Eaton, Zsuzsanna Fluck, Fritz Foley, Tim Habbershon, Richard Locke, Gerald A. McDermott, Ian MacMillan, Leif Melin, Felix Oberholzer-Gee, Bill Schulze, Lloyd Stier, Mary Williams, and Shaker A. Zahr; as well as participants at the William Davidson Institute Conference on Trust, Institutions, and Globalization at the University of Michigan and the Wharton Enterprising Families Conference at the University of Pennsylvania.
} 


\begin{abstract}
The small number of very large family-controlled corporate groups in many countries combined with their long continuity of control and ability to act discretely give these organizations a comparative advantage in political rent-seeking. This advantage is a key part of a self-reinforcing system whereby oligarchic family corporate control, political rent seeking, and low general levels of trust combine to stymie growth.
\end{abstract}




\section{INTRODUCTION}

Many decades of development economics have not eroded the large differences in the per capita incomes of different countries. Indeed, by some measured, the divide between richest nations and the rest has broadened. We argue that a failure to appreciate the self-reinforcing nature of the forces that prevent economic growth lies at the root of this failure.

The widely held firms that characterize big business in the United States, the United Kingdom, and (to a lesser extent) other common law developed economies, are known to be subject to a variety of agency problems. ${ }^{1}$ Despite such agency problems, these economies have achieved and sustained high levels of economic and social development. In contrast, as La Porta et al. (1999) show, widely held firms are the rarest of curiosities in most countries. Consequently, economists turned their attention elsewhere than ownership structure for factors that retard economic development outside these few countries.

Many economists now concur with Krueger (1974) that official corruption is a critical barrier to growth in many countries. Murphy et al. (1991) argue that official corruption diverts resources and talent away from real investments into political rent-seeking: lobbying politicians, influencing judges, and currying favor with bureaucrats. ${ }^{2}$ Lucrative returns from these rentseeking investments 'crowd out' real investment in physical assets, research, and the like, which pay only normal returns. As political rent-seeking is a negative sum game, this investment does not stimulate growth. Indeed, Murphy et al. (1993) argue that the magnitude of this diversion is so large in many countries that it starves real investments, especially investment in innovation, of

\footnotetext{
${ }^{1}$ See Jensen and Meckling (1976) for the essential theory, and Morck et al.(1988, 1989, 1990) and others for empirical evidence on the importance of agency problems and on the mechanisms whereby they are constrained.

${ }^{2}$ We follow standard practice from the economics and finance literatures in using the term political rent seeking to describe self-interested dealings between the political and business elites. The term rent is appropriate in its economic usage, which includes unearned income of any kind. Also, we use the term corrupt, rather than illegal, to describe these transactions and the parties to them. This is because political rent seeking is legal, if not socially acceptable behavior, in many countries.
} 
financing. Since Schumpeter (1934), Solow (1957), and Romer (1986) are now widely accepted as correct in arguing that investment in innovation is critical to growth, Krueger (1974), Murphy et al. (1991, 1993), and others argue that this diversion seriously impedes growth.

Fukuyama (1995), La Porta et al. (1997), and others hold that an absence of general trust in an economy prevents large, professionally managed businesses from developing, and that this also impedes growth for two reasons. First, a lack of trust for outsiders causes family firms to avoid hiring professional managers and to shun growth if this requires external capital. Second, a lack of trust for insiders causes public investors to be wary of entrusting their savings to stocks. Consistent with this, we find that the largest firms in poorer countries are more frequently family controlled.

However, we argue that the interconnections between corruption, low trust, and poverty are more subtle than this, and do involve the nature of corporate ownership - but in a previously unexpected way. In particular, we argue that an absence of general trust, official corruption, and family control of large corporations are mutually reinforcing factors that combine to block growth. Note that this argument applies primarily to very large family-controlled firms, not to the small and medium sized operations that are the typical subjects of research into family firms.

We present empirical evidence consistent with the view that very large family firms are especially good at political rent seeking in many poorer economies. We argue that this makes sense because rent-seeking is essentially a cooperative outcome to a prisoner's dilemma game between a mercantile elite and a political elite. Cooperative outcomes to such games are more likely if the number of participants is smaller, their time horizons longer, their ability to make credible private commitments more sure, their ability to punish a breach of faith more certain, and their contacts with each other more widespread. The small number of large family corporate 
groups in many countries, their long continuity of control, their ability to act discretely, their widespread existing power, and their multiple contacts with governments give these organizations a comparative advantage in political rent-seeking.

This view of why poor nations remain poor has two implications.

First, it explains the inability of many countries to overcome pervasive corruption and oligarchic corporate control. Ending corruption is a hopeless task if a small number of leading families continue to control most business interests and have a comparative advantage in political rent-seeking. Likewise, dislodging established oligarchic families, as sometimes happens after abrupt shifts of political regime, only makes space for a new oligarchy unless the corruption that encourages rent-seeking is discouraged. Moreover, pervasive corporate control by a corrupt oligarchy is likely to reinforce public distrust of the financial system, which prevents professionally managed widely held firms from emerging. We argue that a simultaneous attack on all three pillars of this status quo, and on the institutional arrangements that arise out of their interactions, is required. Pressure to end official corruption should be accompanied by pressure to replace entrenched family firms with professionally managed ones and by aid and educational policies designed to inculcate both trust and the trustworthy behavior necessary to make trust worthwhile.

Second, our results are about statistical averages. Every very large family-controlled firm or group of firms is probably not primarily engaged in political rent-seeking. Some entrenched oligarchic mercantile families might be enlightened and benevolent. Moreover, professional management leads to a well-known set of agency problems that can also impede growth. Further work is needed to clarify how these tradeoffs between the problems of entrenched family oligarchic control and professional management differ in different circumstances. 


\section{FAMILY CONTROL OVER LARGE FIRMS AND ECONOMY PERFORMANCE}

The incidence of family control over very large corporations varies widely across countries. Table 1 shows the fractions of the top twenty publicly traded firms, ranked by market capitalization, in each country that are controlled by families, as reported by La Porta et al. (1999). As a robustness check, family control is defined in two ways: first as a twenty percent voting block, and then as a ten percent voting block. Note that a $51 \%$ voting block is not normally required for control because most small shareholders do not participate in shareholder meetings.

\section{Insert Table 1 About Here}

Family control is least important in the United Kingdom, where no family controls more than twenty percent of the votes of any of the top twenty public firms. In Mexico, all of the top firms are family controlled by this definition Other countries range between these extremes, with Italy having $15 \%$ of its top twenty firms controlled by families, Belgium having $50 \%$ family control, and Sweden having 45\% family control. Using a ten-percent threshold, rather than twenty percent, gives a broadly similar distribution.

The top twenty firms in the United States are larger than the top twenty firms in Singapore. It therefore makes sense to look at a second sample of roughly similar sized firms from each country. Table 1 therefore also shows the incidence of family control in each country for ten middle sized firms, defined here as having market capitalizations greater than US\$500 million. Again, there is substantial variation between countries, and the rankings of countries change somewhat. Most notably, Germany and Italy exhibit a much higher incidence of family control in medium-sized firms than in their largest firms. 
Note that what we call medium sized firms are still quite large by any standards. Table 1 does not include information about small private family firms. All of our family control measures gauge the important of the great mercantile families of each country. Consequently, we interpret these variables as measuring oligarchic family control, as opposed to merely family control.

Although our sample of countries contains no extremely poor countries, it contains most of the major rich and middle-income countries in the world. The first thing one is apt to notice about Table 1 is a general tendency for higher income countries to exhibit a lower incidence of oligarchic family control. Table 2 verifies this by displaying the simple statistical correlations of the oligarchic family control incidence measures in Table 1 with some standard measures of economic and social development, including per capita income.

Table 2 shows that per capita income, represented by the logarithm of each country's 1995 gross domestic product (GDP) per capita is highly significantly negatively correlated with all four measures of oligarchic family control. The poorer the country, the more important are great family firms.

\section{Insert Table 2 About Here}

Although per capita income is a widely-used measure of a country's level of development, it does not capture every dimension of development. By looking at a broader range of development measures, we can perhaps learn more about the economics underlying the lowincome levels in countries with high degrees of oligarchic family control. Table 2 therefore also presents the simple correlations of oligarchic family control with measures of social structure and of the provision of public goods, including physical infrastructure, health, equality, education, and good government. 
To gauge the development of a country's physical infrastructure, we use an average of five scores, one for each of roads, air, ports, telecommunications, and the electric power system, provided by the Global Competitiveness Report for 1996. These scores are from surveys asking businesses about the extent to which each aspect of these aspects of the country's infrastructure meets the needs of business. Higher scores signify more adequate infrastructure. All four measures of the incidence of oligarchic family control are highly significantly negatively correlated with physical infrastructure quality. The less adequate the country's physical infrastructure, the more important are great family firms.

Both per capita income and physical infrastructure are measures of economic development. However, other yardsticks than economic ones can gauge development. In particular, a wide variety of measures of social development can be used.

Table 2 therefore correlates oligarchic family control with two widely used measures of social development - infant mortality and economic inequality. We obtain infant mortality from the World Bank's World Development Indicators database. The logarithm of the 1993 infant mortality rate per thousand live births is highly positively correlated with oligarchic family control. Social inequality is measured by a gini coefficient. To construct a gini coefficient, one graphs the country's income distribution, as in Figure 1, and then measures the area between that curve and a perfect equality distribution, which is represented by a $45^{0}$ line. Our gini coefficient measures are obtained from the World Bank. The further a country's income distribution deviates from perfect equality, the higher is its gini coefficient. Table 2 shows that oligarchic family control is highly statistically correlated with both higher infant mortality and greater income inequality.

Insert Figure 1 About Here 
The quality of a country's education system is yet another dimension of development. Table 2 correlates oligarchic family control with the percent of respondents in a survey, summarized in the provided by the Global Competitiveness Report for 1996, who agreed that "the education system meets the needs of a competitive economy". This measure of the quality of education is highly negatively correlated with the incidence of corporate control by great families.

Finally, as a general measure of the quality of government, we compare average monthly inflation rates from 1990 to 2002. These data are from the World Bank. While high inflation due to wars or crises of various sorts, such factors are not paramount in the 1990s for the countries we study. As a first approximation, we can interpret a chronic high inflation rate is a sign of inconsistent or irresponsible government. Countries with higher incidences of oligarchic family corporate control also have consistently higher inflation.

To summarize, countries in which more firms are controlled by great mercantile families are more backward in a number of dimensions. They are poorer and less egalitarian. They provide worse public goods - including worse infrastructure, worse infant mortality, worse education, and more irresponsible macroeconomic policies.

\section{WHY ARE FAMILY CONTROLLED ECONOMIES BACKWARD?}

Table 2 illustrates a correlation, but is silent as to what causes what. Some latent factor might induce both oligarchic family control and backwardness in certain countries. Or, backwardness might create conditions where oligarchic family control makes economic sense. Or, might a high incidence of oligarchic family control of corporations actually cause economies to be backward? 
All of these views probably have some validity, and none of the authors cited in this section would insist on a single direction of causality. Social and economic phenomena on this scale seldom have simple patterns of cause and effect, and complicated interactions are to be expected. However, some simple observations and deductions are possible.

\section{An Absence of Trust?}

Much recent work proposes a candidate for a latent factor explaining both family control and development - "trust", or ethical norms. Students of the Italian economy have long noted a correlation between the economic and social importance of families in southern Italy and that region's backward economic and social situation. Most famously, Banfield (1958) argues that southern Italy is ruled by an ethical system of amoral familism. Under this ethical system, keeping faith with one's blood kin and long time friends is highly valued, but failing to keep faith with others, especially strangers, is regarded as inevitable. Banfield (p. 116) writes, "Towards those who are not of the family, the reasonable attitude is suspicion. The parent knows that other families will envy and fear the success of his family and that they are likely to seek to do it injury. He must therefore fear them and be ready to do them injury in order that they may have less power to injure him and his."

Putnam (1993) provides empirical evidence supporting Banfield's thesis. Using surveys, Putnam found that southern Italians express a much lower degree of trust in the law-abiding nature of others than do northern Italians. He also found a much lower degree of non-family interaction in southern Italy, with virtually no one participating in clubs, community associations, professional associations, political parties and the like, and argues that this is a manifestation of a low general level of trust for non-kin. In the more prosperous northern regions of Italy, such memberships are common. Putnam defines social capital as a general trust 
in the good faith of fellow citizens, and argues that southern Italy's backwardness is due to a dearth of social capital. This is because its ethical system encourages pervasive cheating and illfaith, which undermines the economy. It also leaves family firms as the only viable economic structures.

Fukuyama (1995) broadens this reasoning, arguing that amoral familism is in fact pervasive in the traditional cultures of most countries in the world, including China, Latin America, Southern Asia, the Middle East, and Africa. He argues that only a few regions northwestern Europe, North America, and Japan - have achieved ethical systems where people have a high degree of trust for strangers in day-to-day business and other interactions. Fukuyama suggests that these ethical norms greatly reduce the cost of economic activity and thereby create a general prosperity. They also allow the most talented to take charge of the country's economic and political life, and consequently allow both professionally run large corporations and stable democracy.

This view is consistent with Khanna and Palepu $(1997,1999,2000,2001,2002)$ and Khanna (2002), who present evidence that certain great family controlled corporate groups prosper in Chile and India. They argue that this is because these groups circumvent markets made dysfunctional by low trust. Firms controlled by the same family can trade with each other, hire from each other, and finance each other without having to rely on India's goods, labor, or capital markets.

However, our data seem inconsistent with this view as a general explanation for our results on oligarchic family control. If family control is related to backwardness because both are associated with low levels of trust, our oligarchic family control variables should be closely correlated with measures of the degree of trust prevalent in each country. Table 3 therefore 
correlates each incidence of family corporate control variable with several survey measures of the level of trust people have in strangers and in family. These measures are from La Porta et al. (1997), who argue that they capture key aspects of social capital. Table 3 shows all of these measures of social capital to be uncorrelated with oligarchic family control.

\section{Insert Table 3 About Here}

These results suggest that, although low trust may well be an important factor in explaining backwardness, it is poorly correlated across countries with family control over great corporations. The relationship between oligarchic family control and backwardness must therefore operate through some other mechanism.

Moreover, the view that a society's ethical norms are entirely exogenous, and that they determine the level of social and economic development can achieve is disputed per se. Fisman and Khanna (1999) explore changing ethical norms, and argue that increasing in the ease of twoway communications, particularly in urbanized economies, causes increased trust in strangers. Locke (2002) shows that local pockets of high trust exist in archetypical low-trust regions like southern Italy and northeastern Brazil. He argues that the existence of these pockets contradicts the thesis that certain cultural milieus cannot sustain prosperity. But, perhaps most fundamentally, ethical systems are the essence of culture. The idea that some cultures are incapable of sustaining prosperity, let alone democracy, has deeply pessimistic implications. For it means that large fractions of the world's population are doomed to poverty and tyranny by their prized traditional cultures and deeply felt ethical systems.

Of course, establishing that 'trust' is not a latent factor explaining the correlation between oligarchic family control and backwardness does not prove that no such latent factor exists. Moreover, the problem with enumerating latent factors and testing each in this way is that 
genuine latent factors must be truly exogenous. They must be historical residues that are not the results of current decisions being made in the contemporary economy. Fukuyama (1995) makes a sustained case for the ambient level of trust for strangers in a country being such a factor. La Porta et al. (1998) argue that a country's legal system is such a factor, however the variables they use to distinguish legal systems do not explain Table 2 either. ${ }^{3}$ It is certainly possible that some other latent factor might explain Table 2, but we feel that exploring other patterns of causation makes more sense than an exhaustive search for increasingly problematic latent factors.

\section{Family Control as an Eroding Historical Residue?}

A second possibility is that more advanced countries might have a lower incidence of family control because their industrial economies are older. Thus, the high incidence of great family control in Mexico could be due to its being in an early stage of industrialization, while the low incidence of family control in Britain could be due to its having been the first nation to industrialize. Perhaps, as time goes by, squabbling Mexican heirs will slowly sell out to public shareholders, and oligarchic family control will fade. If the probability that a family sells out in any given year is $\pi$, with $0<\pi<1$, then the probability that the family will sell out at some point during an $n$ year long interval is $1-(1-\pi)^{n}$. Obviously, as the length of the time interval, $n$, grows large, the probability that the family sells out becomes arbitrarily close to one. ${ }^{4}$ If different countries were at different stages of industrial development, and incidentally had different levels of residual family control, we would observe the correlations in Table 2.

\footnotetext{
${ }^{3}$ Stronger laws protecting public investors from abuse by controlling shareholders, corporate insiders, or capricious officials are correlated with lower levels of family control, however these laws cannot be regarded as exogenously ordained. They might be, for example, reflect the relative lobbying power of different sorts of investors.

${ }^{4}$ This result is called the Borel-Cantelli Lemma, and is a fundamental building block of probability theory. It states that if an event has a non-zero probability of occurring at any given time, then the probability that it will occur eventually over an arbitrarily long period of time is $100 \%$.
} 
While our data provide some support for this view, it does not seem to fully explain the correlations in Table 2. In Table 4, we run ordinary least squares regressions of the form

$$
p=\beta_{0}+\beta_{1} y+\beta_{2} f+\varepsilon
$$

where $p$ is one of the economy characteristics from Table 2, $y$ is the logarithm of 1995 per capita GDP, $f$ is a measure of family control, and $\varepsilon$ is an error term. If family control is merely proxying for level of development, including $y$ as a control should render the coefficient of the family ownership variable, $\beta_{2}$, insignificant. Table 4 presents these regressions for all permutations of economy characteristics and family ownership variables from Table 2.

\section{Insert Table 4 About Here}

Although the level of significance falls for many of the variables, most of the results in Table 2 remain statistically significant. Infant mortality, income inequality, and inflation remain highly significantly correlated with the incidence of great family control. Perhaps more importantly, growth in per capita income remains highly correlated with oligarchic family control after taking into account each country's initial income level. Since we cannot include per capita GDP as a dependent variable (it is the control variable), we regress real growth in per capita GDP from 1990 to 2000 on the logarithm of 1995 per capita GDP and family control. Oligarchic family control is uniformly statistically significant. This means that countries with the same 1995 per capita income grow at rates negatively correlated with their incidence of family control. In short, controlling for per capita income does not cause the incidence of oligarchic family control to lose all its explanatory power.

Furthermore, the extreme view that development simply proceeds at an exogenous pace

cannot explain why different countries develop at different rates, and why the incidence of family ownership should track these rates. France, which began industrialization long before 
Germany or Japan, preserves a higher incidence of family control. Nor can it explain why an industrial tyro like the Republic of Ireland has very little family control. Some countries developed faster than others, and those countries also abandoned control by great mercantile families faster. If all that mattered were the number of years since the beginning of industrialization during which heirs to great family fortunes might sell out, oligarchic family control would be highest in Ireland, intermediate in Germany and Japan, and almost as low in France as in Britain. This is not observed.

\section{Family Control as an Impediment to Growth?}

These empirical results and logical deductions lead us consider the possibility that a high incidence of family control over a country's great corporations per se might retard development. We in no way argue that Banfield (1958), Putnam (1993), Fukuyama (1995), and others are mistaken in stressing the importance of a society's ethical norms. Nor do we object to the argument that, given a longer time period in which to do it, founding families are more likely to sell out. Rather, we argue that an additional mechanism is likely also at work.

The view that oligarchic family control causes poor economic performance is not new. For example, Landes (1949) argues that the generally poor performance of the French economy compared to those of Germany, Great Britain, and the United States, throughout the nineteenth century was caused by the predominance of family firms in France. He argues that French family firms of the period were typically more interested in survival and independence than in growth and innovation. This made them reluctant both to go public and to undertake high-risk ventures. According to Landes, this profound conservatism retarded the performance of the overall economy because family businesses lobbied for protectionism and bailouts, and regarded 
the state as "a sort of father in whose arms [they] could always find shelter and consolation" (p. 50).

We propose that this sort of behavior is typical in economies in which great mercantile families exercise widespread corporate control, and that this, in addition to the other explanations discussed above, accounts for the correlations in Table 2 and the regression coefficients in Table 4.

This proposition requires considerable explanation, and this is the purpose of the next two sections.

\section{Robustness}

The statistical results in Tables 2 through 4 are robust to sensible changes in the variables.

For example, using gross national product throughout rather than gross domestic product generates qualitatively similar results. By this we mean that the signs and patterns of statistical significance in the tables are preserved, though the precise values of the correlation and regression coefficients may differ somewhat. Qualitatively similar results also ensue from replicating Table 4 using GDP growth from 1970 to the present, and using 1970 per capita GDP as the control variable. Using inflation from 1970 also generates qualitatively similar results though the regression coefficients in Table 4 are of a starkly different magnitude, their signs and statistical significance are consonant with those show in the tables.

Using various other measures of economic development, physical infrastructure, health care standards, human development, macroeconomic policy, and income equality also generate qualitatively similar results to those shown. For example, an alternative measure of the quality 
of a country's physical infrastructure, an assessment of "the facilities for and ease of" communications and transportation within the country. This measure, provided by Business Environment Risk Index Corp., generates qualitatively similar results to those shown, though with lower significance levels in the regressions. Using the fraction of males aged 25 and over who completed high school as an alternative measure of the quality of the education system yields also yields qualitatively similar results. It might be argued that the variation in a country's inflation rate is a better indicator of irresponsible government that the mean inflation rate. The standard deviation of a country's inflation rate is also highly significantly positively correlated with oligarchic family control - both in terms of simple correlations and in regressions analogous to Table 4 .

Our sample of countries does not contain any very poor countries. Corporate ownership figures for very poor countries are not generally available on a consistent basis. However, studies or particular poor countries or regions by Fisman (2001), Johnson and Mitton (2002), Khanna and Palepu (1997, 1999, 2000, 2001, 2002), Khanna (2002), and others reveal corporate control predominantly in the hands of a few very wealthy families. Consequently, including these countries would most likely not change our basic results.

\section{FAMILY CONTROL AND THE DETERMINANTS OF GROWTH}

Krueger (1974) argues that the largest barrier to economic growth is political rentseeking, or corruption. If investing a million dollars in research and development yields a $\$ 50,000$ per year perpetual profit, the R\&D has a $5 \%$ return. If investing the same million dollars in a bribe to a politician change a law changed or provide a subsidy that increases profits by $\$ 100,000$ per year in perpetuity, this political rent-seeking investment has a $10 \%$ return. 
Krueger's essential point is that, if the rents the firm can reap from bribing corrupt politicians exceed the profits they can earn from real investment, real investment declines and bribery becomes prevalent. Murphy et al. (1991), Lenway et al. (1996), Mauro (1995), and many others present empirical evidence supporting Krueger's (1974) hypothesis.

Solow (1957) showed that the greater part of economic growth is not due to growth in the quantity of capital or labor. He argued that this large, previously unexplained part economic growth, now called the Solow residual, must be due to ongoing innovation - the production of ever more valuable outputs from relatively less valuable inputs. Solow's finding is now regarded as the primary evidence supporting the thesis of Schumpeter (1934), later formalized by Romer (1986), that innovation is the main engine of economic growth.

Innovation is a positive sum game. Profit maximizing behavior by innovators creates new wealth, increasing the size of the economic pie and thus fueling long-term growth. Rent seeking, in contrast, is a negative sum game. Political rent seeking may be the highest return investment from the viewpoint of each individual or firm, but for society as a whole, it destroys value. This is because the legislative favoritism, subsidies, and the like that are the rewards for successful rent seeking are not new wealth. They are transfers from elsewhere in the economy. Collecting and redistributing these transfers is costly, and also introduces distortions and inefficiencies.

Murphy et al. (1991, 1993) model how highly remunerative rent seeking diverts talent and resources away from real investment, and argue that this is highly detrimental to growth. They propose that, once talented individuals choose careers as either innovators or rent-seekers, they are locked into that career and steadily become more proficient at it. This means that rent 
seeking and innovation both have path-dependent increasing returns to scale. ${ }^{5}$ Economies characterized by widespread innovation become steadily better at it, and consequently grow ever more rapidly because innovation is a positive sum game. Economies characterized by pervasive rent seeking become ever more encumbered by it, and consequently grow ever more slowly because rent seeking is a negative sum game.

The proposition that oligarchic family control causes slow growth thus requires that oligarchic family control be associated with more rent-seeking, less innovation, or both.

\section{RENT-SEEKING AND THE PRISONERS' DILEMMA}

Political rent seeking can be thought of in terms of prisoner's dilemma games, as modeled by Nash $(1950,1953)$. Figure 2 illustrates the archetypal prisoner's dilemma, where the police interrogate two prisoners separately. The police have evidence to convict both prisoners of a minor crime, and suspect they committed a major crime. The police propose a plea bargain to each prisoner. If the prisoner gives evidence against the other for the major crime, his sentence will be reduced from two years to one year. They add that if the other gives evidence against him about the major crime, and he remains silent, he will be assumed to be solely responsible for it and will get twenty years. But if both prisoners give evidence against each other, they will both be held responsible for the major crime and will both get fifteen years.

\section{Insert Figure 2 About Here}

If the prisoners can trust each other, both remain silent and both receive light sentences for the minor crime. But if each is uncertain whether the other will keep faith, each gives evidence against the other. Prisoner A knows that if prisoner B keeps faith, A is better off giving

\footnotetext{
${ }^{5}$ See Morck, Sepanski and Yeung (2001) for empirical evidence of such path dependency in US corporate management.
} 
evidence against $\mathrm{B}$ to get a reduced sentence of one year, rather than two, for the minor crime. Prisoner A also knows that if $\mathrm{B}$ gives evidence against him, $\mathrm{A}$ is better off if he also gives evidence against B, and so gets fifteen years instead of twenty.

In either case, A should provide evidence against B. Going though the same logic, B likewise decides to provide evidence against $\mathrm{B}$. The resulting situation, where a lack of trust leads both parties to reach a sub-optimal situation of fifteen-year sentences, is called a noncooperative equilibrium. Had the two prisoners trusted each other, they could have instead attained the cooperative equilibrium outcome of two-year sentences.

Many economic transactions can be couched in such settings. If a customer fears a supplier might use substandard materials, she avoids buying high value-added items where the potential damage would be worse. If workers fear an employer might cheat them, they minimize the damage by shirking on the job. If an inventor cannot trust a backer to pay him fairly for his innovation, he shuns backing, and his invention is not developed. This reasoning is the basis of Fukuyama's (1995) thesis that higher levels of general trust causes greater prosperity.

Of course, cooperative behavior is not always desirable. Producers ought not to cooperate with each other to sustain monopoly pricing. Nor is the cooperation between politicians and corporate executives that characterizes so-called 'crony capitalism' desirable. Trade protectionism has also been shown to be an example of such reciprocal back scratching among top corporate executives and government officials - and labor leaders as well in many cases. For example, Lenway et al. (1996) document the rent-seeking process whereby the United States government erected trade barriers against steel imports. Using data the collect from Congressional Records, they show a statistical correlation of corporate lobbying activity with firm-specific benefits from subsequent trade barriers, as well as with subsequent CEO and senior 
worker pecuniary benefits. Morck et al. (2000), Rajan and Zingales (2001), and Johnson and Mitton (2002) present empirical evidence that controls on capital inflow to business have been repeatedly also been used to direct financing towards politically favored firms by requiring, for example, local joint venture partners. ${ }^{6}$ Although such capital flow policies have built strong family firms in many countries, their overall social costs and benefits are poorly understood at present.

Political rent seeking can be though of as a prisoners dilemma game between the bribepaying business and the corrupt politician. The politician could take a bribe and not deliver the promised favorable change in the law. Or, the politician could provide a large subsidy and then not receive the expected kickback. The bribe paying firm and the corrupt politician must be able to trust each other to fulfill the terms of their rent-seeking agreement. Since such agreements are technically illegal in most countries, the courts cannot be used to punish defectors. The cooperation must be based on personal credibility.

Game theory sets specific conditions as to when cooperative outcomes are easier to attain. These are:

\section{Genetically programmed cooperation}

Cooperative behavior may be hard-wired into certain aspects of human behavior. This seems to be true for interactions with close blood kin in many species, from social insects to humans. Axelrod and Hamilton (1981) argue that cooperative behavior provides an evolutionary advantage. Nonetheless, humans and ants both engage in lethal warfare. Any genetically innate predisposition to cooperative behavior seems restricted to genetically close relatives, and does

\footnotetext{
${ }^{6}$ We are grateful to Leif Melin for bringing our attention to relevant examples in Thailand's recent history, where protectionist legislation relating to ownership of capital by foreigners greatly advanced key local business families. See 'Family Business in Thailand', by Clayton Hebbard, in Families in Business 11(6) 17-20.
} 
not extend to all general members of the species. Certainly, the strong preference family firms display for limiting the influence of outsiders is consistent with such a limitation. ${ }^{7}$

Fisman (2001) shows that relatives of President Suharto controlled most major Indonesian firms in the mid 1990s. Faccio (2002) shows that this is not an isolated case. The senior corporate executives of important firms in many countries are blood relatives of senior government officials. Consequently, the innate cooperation blood kin accord each other facilitates rent seeking.

If the same oligarchic families that control the country's great corporations are more prominent in its government, the cooperation necessary for rent-seeking is easier to achieve.

\section{Cooperation in repeated games}

In long repeated sequences of Prisoners’ Dilemma games, players can learn to cooperate. This is because one player can punish the other for defecting in one game by defecting in the next. Axelrod (1984) shows that this policy of 'tit-for-tat' with occasional forgiveness generates superior overall payoffs in computer-generated prisoners' dilemma repeated game tournaments against a wide range of alternate strategies. Moreover, Axelrod (1987) shows that behavior closely resembling tit-for-tat emerges spontaneously in repeated sequences of Prisoners' Dilemma games where survival into the next period depends on a player's payoff this period and strategies are randomly modified each period by a genetic algorithm. Cooperative behavior in repeated games, even if learned rather than innate, is a survival trait. This logic underlies the need to establish long relationships with business partners in countries where cooperative behavior is not legally or ethically mandated.

\footnotetext{
${ }^{7}$ For example, see 'Family Firms Fret Over Role of Outsiders', by Clayton Hebbard, The Nation, April 18, 2002
} 
The professional managers in charge of large publicly traded firms often have relatively brief careers at the top, having spent most of their lives rising through the corporate world. In contrast, family controlled firms typically exhibit a more continuity of control, with the patriarch grooming the scion, sometimes for decades.

Long-serving officials - the sort who can best do favors for firms - should find oligarchic family controlled firms more cooperative rent-seeking partners because of the higher likelihood of repeated games.

\section{Cooperation in small groups}

Olson (1965) shows that cooperative behavior is more readily sustained in repeated prisoners' dilemma games with fewer players. This is because detecting and punishing defection is easier if fewer players must be monitored and coordinated. As the number of players grows very large, Olson shows that the non-cooperative outcome emerges with virtual certainty.

La Porta et al. (1998), Claessens et al. (2000, 2002), Faccio and Lang (2001), Faccio et al. (2001), and others show that the most important corporations of most countries are organized into vast groups through pyramidal holding companies, cross holdings, multiple classes of stock, golden shares, and reserved board seats and that these groups are controlled by a small number of very wealthy families in each country. ${ }^{8}$ As Morck et al. (2000) show, these control devices allow one company to control many others, each of which controls yet more companies. These pyramidal structures can be more than a dozen layers high and can encompass hundreds of firms, many of which may be partly publicly owned, and all of which are controlled by a family firm at the pyramid's apex. La Porta et al. (1988) show that such pyramidal corporate group structures

\footnotetext{
${ }^{8}$ See Barca and Becht (2000) for a description of these groups in Europe, Claessens et al. (2000) for East Asian family groups, and Morck et al. (2000) for Canadian family groups. See Faccio and Lang (2001), Claessens et al. (2002), and Morck et al. (2000) for discussions of the behavior of such groups in different economies.
} 
include a large proportion of the largest firms in most countries. The first row of Table 5 shows that countries with a high incidence of oligarchic family control also exhibit a high incidence of pyramidal holding companies. Morck et al. (2000) show that a relatively small number of billionaire families control substantial fractions of the economies of many countries, presumably in this way.

\section{Insert Table 5 About Here}

This highly concentrated corporate control limits the number of potential rent-seeking players with which an official can deal, and so facilitates cooperation.

\section{Credible commitments to cooperate}

If the two parties can make binding promises to each other to act cooperatively, cooperative behavior can be achieved. Fukuyama (1995) argues that this is the purpose of laws and cultures. By subjecting themselves to certain punishment if they act in bad faith, and consequently break either social conventions or the law, the players in a prisoners' dilemma can assure each other that they will act cooperatively. Fukuyama further argues that some legal and ethical systems facilitate cooperative behavior with strangers, while others do not; and that broader cooperation induces more rapid economic growth.

Established wealthy families controlling substantial assets can pay corrupt officials up front for subsequent favors. Upstart firms, even ones with great potential, require political favors first but must promise kickbacks out of uncertain future revenues. Moreover, since rent seeking is technically illegal in most countries, rent-seeking deals must be discrete. As La Porta et al. (1998) show, the corporate groups controlled by the wealthiest families of most countries,

typically include a mixture of public and private firms. By using the revenues or assets of 
private group firms, wealthy families can provide a higher level of discretion to corrupt officials than other potential rent seekers can.

Their established wealth and control over corporate assets, and their ability to act discretely, should make the principals of great family firms and groups more attractive rent seeking partners in the eyes of devious officials.

\section{Punishment for defection is harsh and certain}

If other players can readily detect and punish defectors, defection is both less profitable and less likely. This is the case in games with a small number of players, but apparently can also explain some types of cooperation in large, anonymous groups. For example, Axelrod (1986) shows that cooperative behavior can be sustained in games with many players if the players adopt strategies of punishing not only defectors, but also other players who fail to punish defectors. Fehr and Gächter (2000) show in experiments with volunteers that people, if given the opportunity to do so, punish strangers who defect in prisoners' dilemma games - even at considerable cost to themselves. These experiments were done in developed countries, which Fukuyama (1995) argues have extended cooperative behavior to strangers. It is not presently known whether these results can be replicated in low-income countries. The fact that people in developing economies must spend years building relationships before business interactions are possible suggests that cooperative behavior is not expected in business dealings with strangers. It follows that punishment for non-cooperative behavior with strangers must be light or infrequent in these countries.

Great families that control large firms or corporate groups are perhaps the only rival powers in many countries capable of punishing government officials for failing to keep a 
promise. Their substantial existing wealth and control over a large fraction of the national economy make established wealthy families formidable disciplinarians of corrupt officials who fail to deliver.

This ability to retaliate should make great mercantile families more willing to undertake rent-seeking deals with corrupt officials in the first place.

\section{Multiple points of contact}

The reinforcement that motivates cooperation can stem not just from repeated playing of the same game over time, but also from multiple simultaneous plays. Oligarchic families, controlling dozens or hundreds of firms through pyramidal structures and the like, plausibly interact with important politicians and bureaucrats simultaneously in many different settings. In analyzing the interactions between two diversified conglomerates, Bernheim and Whinston (1990) show that multimarket contacts reduce the incentive constraints that limit collusion. If a similar effect takes place between officials and oligarchic families, this could explain a greater preponderance of rent-seeking collusion in economies dominated economically by a few great families. The logic here is very similar to that underlying the repeated games and certainty of punishment arguments discussed above. A politician who refuses to cooperate with an oligarchic family in one setting may find himself punished by a family operation in an entirely different sector of the economy.

In summary, the most important partners of corrupt officials in rent-seeking deals are likely to be wealthy families that exercise long-term continuous control over very large groups of firms that comprise substantial fractions of national economies. 
Table 5 presents evidence consistent with political rent seeking being significantly more attractive in economies where the incidence of family control is higher. Family firms are more important in countries where the taxation authorities, politicians, judges, and bureaucrats are all significantly more prone to corruption. These differences are statistically significant, and perhaps the most critical one, that pertaining to bureaucratic corruption, remain highly significant after controlling for per capita income.

\section{OTHER PRISONERS' DILEMMAS ASSOCIATED WITH RENT SEEKING}

Although the game between rent seeking firms and corrupt officials is at the heart of political rent seeking arrangements, other prisoners' dilemmas fill in other important parts of the picture.

First, the game between corrupt politicians and rent seeking firms is only possible if the rest of society permits it. Those harmed by the cost of corruption and the dearth of real investment - taxpayers, consumers, and the like - could band together into an association, movement, or political party to expose and punish corrupt officials and corrupting firms. But taxpayers and consumers are not blood kin, not usually engaged in repeated dealings with each other, numerous, unable to make credible commitments to keep faith, unable to identify and punish defectors, and largely unconnected with each other in other contexts. This makes effective cooperation to thwart rent seeking difficult.

Fukuyama (1995) argues that the higher level of trust that prevails in North America, northwestern Europe, and Japan allows people in those countries to form associations, organization, and grass-roots political movements that can curtail corruption among tax authorities, politicians, judges, and bureaucrats. In contrast, countries with low levels of general 
trust cannot sustain such organizations, leaving governments and families the only enduring institutions, and rent seeking a highly profitable investment from the viewpoints of individual oligarchic families and corrupt officials. Consistent with this, Faccio (2002) reports that firms invest more in political connections in countries with more corrupt institutions.

Second, the interaction between the members of a great mercantile family also has aspects of a prisoner's dilemma. If a family member becomes estranged, he can damage the family by exposing its rent seeking deals. Those privy to the family's secrets must be able to trust each other to keep them secret. Family firms occasionally disintegrate because of such infighting. However, our genetic predisposition to cooperate with blood kin probably explains both the rarity of such defections and the high emotions such betrayals elicit in the affected families.

Finally, the oligarchic families in a given country might cooperate, pledging to invest in innovation, rather than rent seeking. This sort of cooperation could potentially leave all the families and officials better off. However, Morck et al. (2000) report that economies more dominated by old family money exhibit statistically significantly lower private sector R\&D spending and patent filings. They also report that Canadian firms controlled by old families spend statistically significantly less on R\&D than other comparable firms. These findings can be explained in several ways. ${ }^{9}$

Schumpeter (1934) argues that the entrepreneurial talent needed to discover and develop innovations is scarce. Moreover, entrepreneurial talent, like other dimensions of intelligence is, at most, only partially inherited. Heirs several generations removed from the founder of the

\footnotetext{
${ }^{9}$ Hall et al. (2001) distinguish entrepreneurial family firm cultures from non-entrepreneurial ones. While specific family firms may indeed be entrepreneurial, the evidence in Morck et al. (2000) and Morck and Yeung (2002) suggests non-entrepreneurial cultures are more commonplace in the old-money family mercantile empires that are the focus of this study.
} 
family empire may have scant entrepreneurial talent. This means efficient investment in innovation likely requires bringing in professional managers, and so threatens the oligarchic family's control. Given the advantages such families have in rent seeking, eschewing innovation and embracing rent seeking makes sense. The oligarchic family both uses its comparative advantage and further entrenches itself in the sense of Shleifer and Vishny (1989) by locking in a corporate strategy that requires the family's continued control.

Olson (1963) shows, rapid growth is likely to have a destabilizing effect. If wealthy, established families invest in innovation, and this increases the economy's growth rate, they run the risk of destabilizing an economic order in which they currently have high positions. Such considerations are likely to infuse established wealthy families with a conservative bias and a suspicion of innovation, as reported by Landes (1949).

Morck and Yeung (2002) argue that creative destruction in economies whose large firms are mainly controlled by a few wealthy families would better be termed creative self-destruction. Creative destruction is the economic process of innovation described by Schumpeter (1934), whereby creative firms devise innovations and destroy moribund firms by depriving them of business. In an economy of many independent firms, the destruction is visited upon old firms and does not enter the cost benefit analysis of the innovator. In an economy where a few oligarchic families control most major corporations, one firm's innovation may threaten the sales of another existing firm controlled by the same family. This internalization of creative destruction lowers its overall return to the controlling family. This can make innovation unattractive to the family even when it makes economic sense for the innovating firm and for the 
economy as a whole. ${ }^{10}$ Consistent with this view, He et al. (2002) find that a higher turnover in the ranks of businesses is associated with faster economy-wide productivity growth.

Schumpeter (1934) argues that innovation requires well-functioning financial markets and institutions, for innovators are generally not wealthy and require financial backing. Consistent with this, King and Levine (1993), Rajan and Zinglaes (1998), Wurgler (2000), and Henry (2000) show that financial development is highly correlated with economic growth. Backing politicians and officials who would interfere with the efficient operations of the financial system is thus a particularly useful for of rent seeking, for this can prevent innovative new firms from rising to threaten established family businesses. Rajan and Zingales (2001) argue that this is precisely what happened in many civil law countries during the twentieth century. Morck et al. (2000) and Johnson and Mitton (2002) describe how dominant families prefer dysfunctional financial systems because these serve as barriers to entry - limiting competition from upstarts, and locking in the dominant positions of (their) established firms.

In addition, Claessens et al. (2002), Faccio et al. (2001), and others document systematic abuse of public shareholders by controlling families of corporate groups across a wide range of East Asian and European countries. ${ }^{11}$ These families may merely prefer weak financial systems because stronger ones would restrict such behavior. Undermining the financial system nonetheless impedes growth by preventing innovators from obtaining financial backing on efficient terms.

\footnotetext{
${ }^{10}$ This situation can occur in any large firm. For example, Betz (1997) documents how IBM top executives delayed that company's efforts in PCs out of fear that PCs would marginalize the mainframe business that was their area of expertise. We propose that such situations are more likely in economies where a few individuals or families control most major corporations.

${ }^{11}$ Actions by controlling shareholders that would qualify as abusive in the United States are often perfectly legal in these countries. See la Porta et al. (1998) for a survey of these legal differences, and see Johnson et al. (2000) for the details of specific cases.
} 


\section{A LOW INCOME - LOW TRUST TRAP?}

The considerations discussed in the previous sections suggest the possibility of destructive self-reinforcing feedback between oligarchic family control, rent seeking, and poverty.

The wealthy established families that economically dominate many countries are active and adept rent seekers. They fear innovation because it might erode their dominance, and they use their rent seeking skills to block the entry of innovators by undermining the financial system. Once such political rent-seeking deals are routine, neither individual wealthy families nor individual officials benefit by curtailing them. The result is that an economy dominated by political rent seeking and locked into poverty.

Although Table 3 did not show a strong link between family control and measures of trust. Nonetheless, this self-serving behavior and widespread political corruption might erode trust for non-kin among the population in general. This lack of trust might then be one factor preventing ordinary people from coalescing into political parties and other organizations that might check corruption and the power of the established families. However, Table 3 clearly indicates that other facets must predominate.

\section{SOME CAVEATS}

The empirical evidence we have presented, both in the tables and in the other studies discussed above, is consistent with this mutually reinforcing model of low trust economies. However, it does not prove the case. This is because correlations do not necessarily imply causal relationships. Low income might 'cause' oligarchic family domination, widespread rentseeking, and a dysfunctional financial sector, leaving no causal relationship per se between 
family domination and rent-seeking or between family domination and a dysfunctional financial sector.

The most unambiguous tests of causality are 'event studies', where one of the variables of interest changes for exogenous reasons. The resultant changes in the other variables then allow clear inferences about what causes what. Unfortunately, we have only a single year crosssection measuring the incidence of family control, so such techniques are beyond the scope of the current study. Causality can also sometimes be inferred from instrumental variables techniques, however no econometrically useful instruments are available. For example, using lagged independent variables as instruments is questionable because all of our variables change slowly over time. Per capita GDP in 1970 is highly correlated with 1994 per capita GDP. If they were available, measures of corruption and family dominance in the two years would also be highly correlated through time. In such a setting, instrumental variables techniques can produce misleading inferences of causality.

However, our purpose is not to unravel what is, in any case, a very complicated web of causality. Rather, we wish to highlight how the mechanisms discussed above reinforce each other to create a low-income trap, which we believe limits the standards of living of the peoples of many countries. An effective trap can be constructed in many ways.

\section{IMPLICATIONS AND CONCLUSIONS}

By some measures, the gap in per capita income between richer and poorer nations is wider than ever. We propose that a failure to appreciate the economic implications of oligarchic family corporate groups may be at least partly responsible. 
The World Bank and International Monetary Fund have come to appreciate the importance of corruption in perpetuating poverty. This is the primary motivation for the current emphasis these institutions place on structural reform, which has become an abbreviation for cleaning up corruption of all sorts. The self-reinforcing nature of the low-income trap we describe suggests that ending corruption may be a hopeless task if a small number of oligarchic families continue to control most business interests in poor countries.

Equally, displacing the existing elite, as sometimes happens after abrupt shifts in political regimes, and as Olsen (1982) recommends, is also unlikely to bring about real change unless the relative return to rent seeking is also lowered. After such a disruption, new leading families with political connections should quickly take the place of those who were ejected.

Ultimately, what is required is a joint attack on both. Pressure to end official corruption should be accompanied by pressure to replace entrenched family firms with professionally managed ones. Since the economic dominance of a corrupt oligarchy of great mercantile families is likely to inspire a general lack of trust in a country's institutions, establishing a high level of trust, as advocated by Fukuyama (1995, 1995a) probably requires breaking this selfreinforcing cycle of corruption and oligarchic control. Moreover, a (realistic) high level of trust makes professional management possible by allowing public equity markets to develop. 


\section{REFERENCES}

Axelrod, Robert, and Hamilton, William. 1981. The Evolution of Cooperation in Biological Systems. Science, 211(27), 1390-96.

Axelrod, Robert. 1984. The Evolution of Cooperation. Basic Books.

Axelrod, Robert. 1986. An Evolutionary Approach to Norms. American Political Science Review, 80(4), 1095-1111.

Axelrod, Robert. 1987. The Evolution of Strategies in the Iterated Prisoners' Dilemma. In Lawrence Davis (ed.), Genetic Algorithms and Simulated Annealing. Los Altos, CA: Morgan Kaufman.

Banfield, Edward. 1958. The Moral Basis of a Backward Society. Glencoe IL: Free Press.

Barca, Fabrizio and Becht, Marco, eds. 2000. The Control of Corporate Europe. Oxford University Press.

Bernheim, B. Douglas and Michael Whinston. 1990. Multimarket Contact and Collusive Behavior. Rand Journal of Economics 21(1) 1-26.

Betz, Frederick. 1997. Managing Technological Innovation: Competitive Advantage from Change. John Wiley \& Sons. New York.

Claessens Stijn, Djankov, Simeon, Lang, Larry H.P. 2000. The separation of ownership and control in East Asian Corporations, Journal of Financial Economics, 58(1-2), 81-112.

Claessens, Stjin, Djankov, Simeon, Fan, Joseph and Lang, Larry. 2002. Expropriation of minority shareholders in East Asia. Journal of Finance, forthcoming.

Faccio, Mara and Lang, Larry H.P. 2001. The Separation of Ownership and Control: An Analysis of Ultimate Ownership in Western European Countries. Working paper. 
Faccio, Mara, Lang, Larry and Young, Leslie. 2001. Dividends and expropriation. American Economic Review, 91(1), 54-78.

Faccio, Mara. 2002. Politically Connected Firms - Can They Squeeze the State? University of Notre Dame working paper.

Fehr, Ernst and Gächter, Simon. 2000. Cooperation and Punishment in Public Goods Experiments. American Economic Review, 90(4), 980-994.

Fisman, Raymond, and Khanna, Tarun. 1999. Is Trust a Historical Residue? Information Flows and Trust Levels. Journal of Economic Behavior and Organization, 38(1), 79-92.

Fisman, Raymond. 2001. Estimating the value of political connections. American Economic Review, 91(4), 1095-1103.

Fukuyama, Francis. 1995. Trust: The Social Virtues and the Creation of Prosperity. Free Press.

Fukuyama, Francis. 1995a. Social Capital and the Global Economy. Foreign Affairs, 74(5), 89104.

Gambetta, D. (1988) Can We Trust Trust? In D. Gambetta (ed.), Trust - Making and Breaking Cooperative Relations. New York: Basil Blackwood.

Hall, Annika, Leif Melin, and Mattias Nordqvist. 2001. Entrepreneurship as radical change in the family business: Exploring the role of cultural patterns. Family Business Review 14(3) 193-208.

He, Kathy, Morck, Randall and Yeung, Bernard. 2002. Stability. University of Alberta working paper.

Henry, Peter Blair. 2000. Do stock market liberalizations cause investment booms? Journal of Financial Economics, 58(1-2), 301-334. 
Högfeldt, Peter and Holmén, Martin. 2001. Ownership and Control in Sweden: Strong Owners, Weak Minorities, and Social Control. In Marco Becht and Colin Mayer (eds.), The Control of Corporate Europe. Oxford University Press.

Jensen, Michael and William Meckling 1976. The Theory of the Firm: Managerial Behavior, Agency Costs and Ownership Structure. Journal of Financial Economics. 3 305-360.

Johnson, Simon, and Mitton, Todd. 2002. Who Gains from Capital Controls? Evidence from Malaysia. Journal of Financial Economics. Forthcoming.

Johnson, Simon, La Porta, Rafael, Lopez-de-Silanes, Florencio, and Shleifer, Andrei. 2000. Tunneling. American Economic Review, 90(2), May 22-27.

Khanna, T. and Palepu, K. 1997. Why Focused Strategies May be Wrong for Emerging Markets. Harvard Business Review, July-August 1997.

Khanna, Tarun and Palepu, Krishna. 1999. Policy Shocks, Market Intermediaries, and Corporate Strategy: Evidence from Chile and India. Journal of Economics and Management Strategy, 8(2).

Khanna, Tarun and Palepu, Krishna. 2000. Is group affiliation profitable in emerging markets? An analysis of diversified Indian business groups. Journal of Finance, 55(2), April, 867893. Formerly titled "Corporate Strategy and Institutional Context: An Empirical Analysis of Diversified Indian Business Groups." Harvard Business School Working Paper \#96-051.

Khanna, Tarun and Palepu, Krishna. 2001. Emerging Market Business Groups, Foreign Investors, and Corporate Governance. In R. Morck (ed.), Concentrated Corporate Ownership. National Bureau of Economic Research Conference Volume. University of Chicago Press. 
Khanna, Tarun and Palepu, Krishna. 2002. The Future of Business Groups in Emerging Markets: Long Run Evidence from Chile. Academy of Management Journal, forthcoming.

Khanna, Tarun. 2002. Business Groups and Social Welfare in Emerging Markets: Existing Evidence and Unanswered Questions. European Economic Review, forthcoming.

King, Robert and Levine, Ross. 1993. Finance and Growth: Schumpeter Might Be Right. Quarterly Journal of Economics, 108(3), 717-737.

Krueger, Anne. 1974. The Political Economy of the Rent-Seeking Society. American Economic Review, 64, 291-303.

La Porta, Rafael, Lopez-de-Salinas, Florencio, Shleifer, Andrei and Vishny, Robert. 1997. Legal Determinants of External Finance. Journal of Finance, 52(3), 1131-1150.

La Porta, Rafael, Lopez-de-Salinas, Florencio, Shleifer, Andrei and Vishny, Robert. 1997. Trust in large organizations. American Economic Review, 87(2), 333-339.

La Porta, Rafael, Lopez-de-Salinas, Florencio, Shleifer, Andrei and Vishny, Robert. 1998. Law and Finance. Journal of Political Economy, 106(6), 1113-1157.

La Porta, Rafael, Lopez-de-Salinas, Florencio, Shleifer, Andrei and Vishny, Robert. 1999. Corporate Ownership Around the World. Journal of Finance, 54(2), 471-520.

Landes, David. 1949. French Entrepreneurship and Industrial Growth in the Nineteenth Century. Journal of Economic History, 9, 45-61.

Lenway, Stephanie, Morck, Randall and Yeung, Bernard. 1996. Rent Seeking, Innovation and Protectionism and the American Steel Industry: An Empirical Study, Economic Journal, 106(435), 410-421.

Locke, Richard. 2002. Building Trust. MIT working paper.

Mauro, Paolo. 1995. Corruption and Growth. Quarterly Journal of Economics, 110(3), 681-711. 
Morck, Randall, Andrei Shleifer and Robert Vishny. 1988. Management Ownership and Market Valuation: An Empirical Analysis. Journal of Financial Economics, Vol. 20, No. 1/2, Jan./Mar. 293-315.

Morck, Randall, Andrei Shleifer and Robert Vishny. 1989. Alternative Mechanisms for Corporate Control. American Economic Review. 79(4) 842-852.

Morck, Randall, Andrei Shleifer and Robert Vishny. 1990. Do Managerial Objectives Drive Bad Acquisitions? Journal of Finance. March. 45(1) 31-48.

Morck, Randall, David A. Stangeland, and Bernard Yeung. 2000. Inherited Wealth, Corporate Control, and Economic Growth: The Canadian Disease. In R. Morck ed. Concentrated Corporate Ownership. National Bureau of Economic Research Conference Volume. University of Chicago Press. Previously circulated as National Bureau of Economic Research working paper \#6814 (1998).

Morck, Randall, Sepanski, J. and Yeung, Bernard. 2001. Habitual and Occasional Lobbyers in the US Steel Industry - An EM Algorithm Approach. Economic Inquiry, forthcoming.

Morck, Randall and Yeung, Bernard. 2002. The Political Economy of the Family Firm. Entrepreneurship Theory and Practice. Forthcoming.

Murphy, Kevin M., Shleifer, Andrei and Vishny, Robert W. 1991. The Allocation of Talent: Implications for Growth. Quarterly Journal of Economics, May, 503-530.

Murphy, Kevin M., Shleifer, Andrei and Vishny, Robert W. 1993. Why is Rent-seeking Costly to Growth? American Economic Review, May 82(2), 409-414.

Nash, John. 1950. The Bargaining Problem. Econometrica, 18(2), 286-295.

Nash, John. 1953. Two Person Cooperative Games. Econometrica, 21(1), 128-140. 
Nelson, Richard and Winter, Sidney. 1982. An Evolutionary Theory of Economic Change. Harvard University Press.

Nowak, Martin, Page, Karen and Sigmund, Karl. 2000. Fairness versus Reason in the Ultimatum Game. Science, 289 (September 8), 1773-1775.

Olson, Mancur Jr. 1963. Rapid Growth as a Destabilizing Force, Journal of Economic History, 23(4), 529-552.

Olson, Mancur Jr. 1982. The Rise and Decline of Nations. New Haven: Yale University Press.

Olson, Mancur. 1965. The Logic of Collective Action. Harvard University Press.

Putnam, Robert. 1993. Making Democracy Work: Civic Traditions in Modern Italy. Princeton University Press.

Rajan, Raghuram and Zingales, Luigi. 1998. Financial dependence and growth. American Economic Review, 88(3), 559-586.

Rajan, Raghuram and Zingales, Luigi. 2001. The Great Reversals: The Politics of Financial Development in the $20^{\text {th }}$ Century. National Bureau of Economic Research working paper 8178.

Romer, Paul. 1986. Increasing returns and long-run growth. Journal of Political Economy, 94(5), $1002-1037$.

Schumpeter, Joseph. 1934. The Theory of Economic Development. Harvard University Press.

Shleifer, Andrei, and Vishny, Robert. 1989. Management Entrenchment: The Case of ManagerSpecific Investments. Journal of Financial Economics, Nov. 25(1), 123-140.

Solow, Robert. 1957. Technical Change and the Aggregate Production Function. Review of Economics and Statistics, 39, 312-20. 
Weber, Max. 1920. The Protestant Ethic and the Spirit of Capitalism. Republished in 1958 by Scribner's Press, New York.

Wurgler, Jeffrey. 2000. Financial Markets and the Allocation of Capital. Journal of Financial Economics, 58, 187-214. 


\section{Figure 1}

\section{Measuring Inequality}

Inequality is measured by the gini coefficient, the area between a country's actual income distribution and a perfect equality income distribution, represented by the forty-five degree line. The larger the are between the two functions, the greater the income inequality.

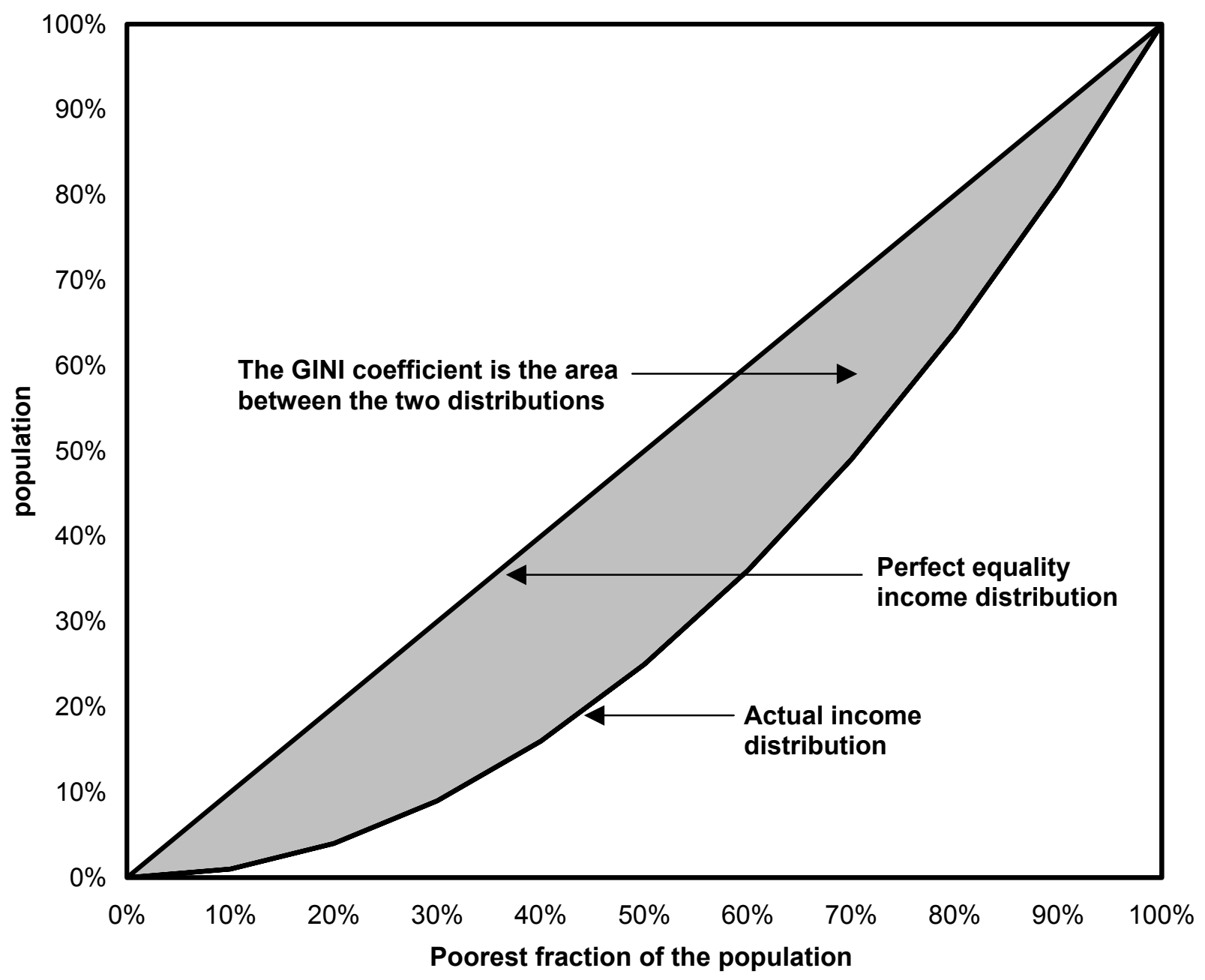




\section{Figure 2}

\section{The Prisoner's Dilemma}

The police have solid evidence that two miscreants are guilty of a minor crime, and suspect that they are also guilty of a major crime. Keeping the two prisoners separate, they explain to each that, if he gives evidence against the other for the major crime, his sentence will be reduced from two years to one year. They add that if the other gives evidence against him about the major crime, and he remains silent, he will be assumed solely responsible for it and will get twenty years. But if both prisoners give evidence against each other, they will both be held responsible for the major crime and will both get fifteen years. Prisoner A knows that if prisoner B keeps faith, $A$ is better off giving evidence against $B$ to get a reduced sentence of one year, rather than two, for the minor crime. Prisoner A also knows that if $B$ gives evidence against him, $A$ is better off if he also gives evidence against $B$, and so gets fifteen years instead of twenty. In either case, $A$ should provide evidence against $B$. The same logic leads $B$ to provide evidence against $B$. This situation, where a lack of trust leads to a sub-optimal situation of fifteen-year sentences, is called a non-cooperative equilibrium. Had the two prisoners trusted each other, they could have instead attained the cooperative equilibrium outcome of two-year sentences.

\begin{tabular}{|c|c|c|c|}
\hline & \multicolumn{2}{|c|}{ B's decision } \\
\hline & & keep faith & defect \\
\hline \multirow{2}{*}{ A's decision } & keep faith & $\begin{array}{l}P(\mathrm{~A})=-2 \\
P(\mathrm{~B})=-2\end{array}$ & $\begin{array}{l}P(\mathrm{~A})=-20 \\
P(\mathrm{~B})=-1\end{array}$ \\
\hline & defect & $\begin{array}{l}P(\mathrm{~A})=-1 \\
P(\mathrm{~B})=-20\end{array}$ & $\begin{array}{l}P(\mathrm{~A})=-15 \\
P(\mathrm{~B})=-15\end{array}$ \\
\hline
\end{tabular}




\section{Table 1}

\section{The Incidence of Family Control in Different Countries}

Family control is inferred if the largest shareholder is a family and if its stake is greater than either a $20 \%$ or $10 \%$ voting-control threshold. Family control is assigned to the twenty largest publicly traded firms, ranked by December 1995 market capitalization, in each country; and for ten randomly chosen medium sized firms, with market capitalization greater than $\$ 500$ million in December 1995.

\begin{tabular}{|c|c|c|c|c|}
\hline \multirow[b]{2}{*}{ Country } & \multicolumn{2}{|c|}{$\begin{array}{l}\text { Twenty Largest } \\
\text { Firms }\end{array}$} & \multicolumn{2}{|c|}{$\begin{array}{l}\text { Ten Middle-size } \\
\text { Firms }\end{array}$} \\
\hline & $\begin{array}{c}20 \% \\
\text { Threshold }\end{array}$ & $\begin{array}{c}10 \% \\
\text { Threshold }\end{array}$ & $\begin{array}{c}20 \% \\
\text { Threshold }\end{array}$ & $\begin{array}{c}10 \% \\
\text { Threshold }\end{array}$ \\
\hline Argentina & $65 \%$ & $65 \%$ & $80 \%$ & $80 \%$ \\
\hline Australia & $5 \%$ & $10 \%$ & $50 \%$ & $50 \%$ \\
\hline Austria & $15 \%$ & $15 \%$ & $17 \%$ & $17 \%$ \\
\hline Belgium & $50 \%$ & $50 \%$ & $40 \%$ & $40 \%$ \\
\hline Canada & $25 \%$ & $30 \%$ & $30 \%$ & $50 \%$ \\
\hline Denmark & $35 \%$ & $35 \%$ & $40 \%$ & $40 \%$ \\
\hline Finland & $10 \%$ & $10 \%$ & $20 \%$ & $20 \%$ \\
\hline France & $20 \%$ & $20 \%$ & $50 \%$ & $50 \%$ \\
\hline Germany & $10 \%$ & $10 \%$ & $40 \%$ & $40 \%$ \\
\hline Greece & $50 \%$ & $65 \%$ & $100 \%$ & $100 \%$ \\
\hline Hong Kong & $70 \%$ & $70 \%$ & $90 \%$ & $90 \%$ \\
\hline Ireland & $10 \%$ & $15 \%$ & $13 \%$ & $25 \%$ \\
\hline Israel & $50 \%$ & $50 \%$ & $60 \%$ & $60 \%$ \\
\hline Italy & $15 \%$ & $20 \%$ & $60 \%$ & $80 \%$ \\
\hline Japan & $5 \%$ & $10 \%$ & $10 \%$ & $10 \%$ \\
\hline Mexico & $100 \%$ & $100 \%$ & $100 \%$ & $100 \%$ \\
\hline Netherlands & $20 \%$ & $20 \%$ & $20 \%$ & $20 \%$ \\
\hline New Zealand & $25 \%$ & $45 \%$ & $29 \%$ & $86 \%$ \\
\hline Norway & $25 \%$ & $25 \%$ & $40 \%$ & $40 \%$ \\
\hline Portugal & $45 \%$ & $50 \%$ & $50 \%$ & $50 \%$ \\
\hline Singapore & $30 \%$ & $45 \%$ & $40 \%$ & $60 \%$ \\
\hline South Korea & $20 \%$ & $35 \%$ & $50 \%$ & $80 \%$ \\
\hline Spain & $15 \%$ & $25 \%$ & $30 \%$ & $30 \%$ \\
\hline Sweden & $45 \%$ & $55 \%$ & $60 \%$ & $60 \%$ \\
\hline Switzerland & $30 \%$ & $40 \%$ & $50 \%$ & $50 \%$ \\
\hline United Kingdom & $0 \%$ & $5 \%$ & $40 \%$ & $60 \%$ \\
\hline United States & $20 \%$ & $20 \%$ & $10 \%$ & $30 \%$ \\
\hline
\end{tabular}

Source: La Porta et al. (1999). 
William Davidson Institute Working Paper 585

\section{Table 2}

\section{Economy Characteristics and the Incidence of Family Control}

\begin{tabular}{|c|c|c|c|c|c|}
\hline & \multicolumn{4}{|c|}{ Simple Correlation Coefficients } & \multirow[b]{3}{*}{ sample } \\
\hline & \multicolumn{2}{|c|}{ Twenty Largest Firms } & \multicolumn{2}{|c|}{ Ten Middle-size Firms } & \\
\hline & $\begin{array}{c}20 \% \\
\text { Threshold }\end{array}$ & $\begin{array}{c}10 \% \\
\text { Threshold }\end{array}$ & $\begin{array}{c}20 \% \\
\text { Threshold }\end{array}$ & $\begin{array}{c}10 \% \\
\text { Threshold }\end{array}$ & \\
\hline \multicolumn{6}{|l|}{ Economic Development } \\
\hline $\begin{array}{l}\text { Logarithm of } 1995 \text { per capita GDP in current } \\
\text { international dollars at PPP }\end{array}$ & $\begin{array}{l}-0.514 \\
(0.01)\end{array}$ & $\begin{array}{l}-0.577 \\
(0.00)\end{array}$ & $\begin{array}{r}-0.560 \\
(0.00)\end{array}$ & $\begin{array}{r}-0.564 \\
(0.00)\end{array}$ & 27 \\
\hline \multicolumn{6}{|l|}{ Physical Infrastructure } \\
\hline $\begin{array}{l}\text { Average scores for roads, air, ports, telecom, \& } \\
\text { power for how well each meets business needs }\end{array}$ & $\begin{array}{r}-0.354 \\
(0.08)\end{array}$ & $\begin{array}{r}-0.398 \\
(0.05)\end{array}$ & $\begin{array}{r}-0.553 \\
(0.00)\end{array}$ & $\begin{array}{r}-0.480 \\
(0.02)\end{array}$ & 25 \\
\hline \multicolumn{6}{|l|}{ Health Care } \\
\hline Logarithm of infant mortality rate per 1,000, 1993 & $\begin{array}{l}0.757 \\
(0.00)\end{array}$ & $\begin{array}{l}0.749 \\
(0.00)\end{array}$ & $\begin{array}{l}0.653 \\
(0.00)\end{array}$ & $\begin{array}{l}0.665 \\
(0.00)\end{array}$ & 25 \\
\hline \multicolumn{6}{|l|}{ Human Development } \\
\hline $\begin{array}{l}\text { Percent of respondents who agreed that the } \\
\text { education system meets the needs of a competitive } \\
\text { economy }\end{array}$ & $\begin{array}{r}-0.439 \\
(0.03)\end{array}$ & $\begin{array}{r}-0.422 \\
(0.04)\end{array}$ & $\begin{array}{r}-0.551 \\
(0.00)\end{array}$ & $\begin{array}{r}-0.519 \\
(0.01)\end{array}$ & 25 \\
\hline \multicolumn{6}{|l|}{ Macroeconomic Policy } \\
\hline Average monthly inflation, 1990-2002 & $\begin{array}{l}0.709 \\
(0.00)\end{array}$ & $\begin{array}{l}0.699 \\
(0.00)\end{array}$ & $\begin{array}{l}0.689 \\
(0.00)\end{array}$ & $\begin{array}{l}0.602 \\
(0.00)\end{array}$ & 25 \\
\hline \multicolumn{6}{|l|}{ Equality } \\
\hline Income inequality as measured by a Gini coefficient & $\begin{array}{l}0.547 \\
(0.00)\end{array}$ & $\begin{array}{l}0.541 \\
(0.00)\end{array}$ & $\begin{array}{l}0.504 \\
(0.01)\end{array}$ & $\begin{array}{l}0.491 \\
(0.01)\end{array}$ & 27 \\
\hline
\end{tabular}

Numbers in parenthesis are probability levels for the null hypothesis of zero correlation or zero regression coefficient. Incidence of control is as of 1995. 


\section{Table 3}

\section{Measures of Trust and the Incidence of Family Control}

\begin{tabular}{|c|c|c|c|c|c|}
\hline & \multicolumn{4}{|c|}{ Simple Correlation Coefficients } & \\
\hline & \multicolumn{4}{|c|}{ Incidence of Family Control in 1995 in } & \\
\hline & \multicolumn{2}{|c|}{ Twenty Largest Firms } & \multicolumn{2}{|c|}{ Ten Middle-size Firms } & \\
\hline & $\begin{array}{c}20 \% \\
\text { Threshold }\end{array}$ & $\begin{array}{c}10 \% \\
\text { Threshold }\end{array}$ & $\begin{array}{c}20 \% \\
\text { Threshold }\end{array}$ & $\begin{array}{c}10 \% \\
\text { Threshold }\end{array}$ & Samole \\
\hline $\begin{array}{l}\text { Survey results of the extent to } \\
\text { which people trust strangers }\end{array}$ & $\begin{array}{l}-0.234 \\
(0.31)\end{array}$ & $\begin{array}{l}-0.243 \\
(0.29)\end{array}$ & $\begin{array}{l}-0.359 \\
(0.11)\end{array}$ & $\begin{array}{r}-0.332 \\
(0.14)\end{array}$ & 21 \\
\hline $\begin{array}{l}\text { Survey results for how much } \\
\text { people trust their families }\end{array}$ & $\begin{array}{l}-0.015 \\
(0.95)\end{array}$ & $\begin{array}{l}0.043 \\
(0.86)\end{array}$ & $\begin{array}{l}-0.037 \\
(0.88)\end{array}$ & $\begin{array}{l}0.106 \\
(0.66)\end{array}$ & 20 \\
\hline $\begin{array}{l}\text { The incidence of membership } \\
\text { in professional associations }\end{array}$ & $\begin{array}{l}-0.278 \\
(0.22)\end{array}$ & $\begin{array}{l}-0.276 \\
(0.23)\end{array}$ & $\begin{array}{l}-0.337 \\
(0.14)\end{array}$ & $\begin{array}{l}-0.216 \\
(0.35)\end{array}$ & 21 \\
\hline $\begin{array}{l}\text { Index of the extent of civic } \\
\text { participation }\end{array}$ & $\begin{array}{l}-0.140 \\
(0.54)\end{array}$ & $\begin{array}{l}-0.182 \\
(0.43)\end{array}$ & $\begin{array}{l}-0.326 \\
(0.15)\end{array}$ & $\begin{array}{l}-0.273 \\
(0.23)\end{array}$ & 21 \\
\hline
\end{tabular}


William Davidson Institute Working Paper 585

\section{Table 4}

\section{Economy Characteristics and the Incidence of Family Firms, Controlling for Per Capita Income}

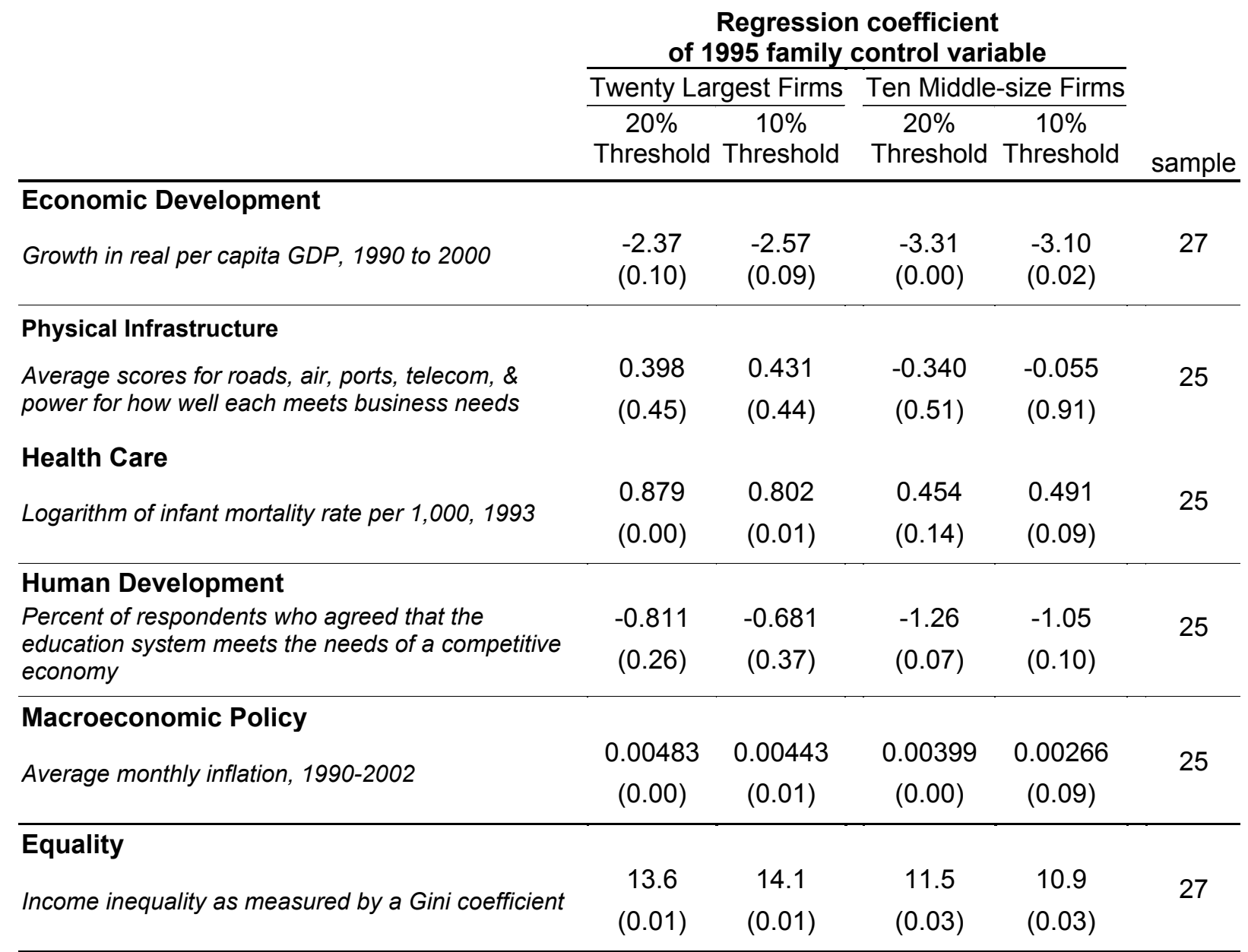

Numbers in parenthesis are probability levels for the null hypothesis of zero correlation or zero regression coefficient. Regressions are of the form

economy characteristic $=a+b$ x family control incidence $+c \times$ logarithm of 1995 per capita GDP $+e$. 


\section{Table 5}

\section{Measures of the Return to Political Rent Seeking and the Incidence of Family Firms}

Simple Correlation Coefficients

\begin{tabular}{|c|c|}
\hline \multicolumn{2}{|c|}{ Incidence of Family Control in 1995 in } \\
\hline Twenty Largest Firms & Ten Middle-size Firms \\
\hline hro & robs \\
\hline
\end{tabular}

Regression Coefficients controlling for log of 1995 per capita GDP Incidence of Family Control in 1995 in Twenty Largest Firms Ten Middle-size Firms $20 \% \quad 10 \% \quad 20 \% \quad 10 \%$ Threshold Threshold Threshold Threshold

\section{Control Concentration}

Incidence of pyramidal holding company structures

crashold

$\begin{array}{llll}0.313 & 0.357 & 0.108 & 0.157 \\ (0.11) & (0.07) & (0.59) & (0.43)\end{array}$

0.418
$(0.13)$

0.529

$\begin{array}{ll}0.079 & 0.154 \\ (0.77) & (0.56)\end{array}$

\section{Tax System Corruption}

Higher scores indicate general compliance with tax laws

$\begin{array}{llll}-0.470 & -0.444 & -0.472 & -0.270 \\ (0.02) & (0.03) & (0.02) & (0.19)\end{array}$

$\begin{array}{llll}-0.889 & -0.588 & -0.732 & 0.470 \\ (0.32) & (0.54) & (0.40) & (0.57)\end{array}$

\section{Political System Corruption}

Higher scores indicate a general absence of official corruption

$-0.414$

$(0.03)$

$-0.438$

(0.02)

(0.19)

(0.32)

$(0.54)$

$(0.40)$

$(0.57)$

$\begin{array}{llll}0.367 & 0.188 & -1.05 & -0.980\end{array}$

$\begin{array}{llll}(0.73) & (0.87) \quad(0.31) \quad(0.33)\end{array}$

\section{Judicial System Corruption}

The efficiency and integrity of the judicial system, particularly as it affects business

$\begin{array}{ll}-0.340 & -0.375 \\ (0.08) & (0.05)\end{array}$

$-0.526$

$-0.523$

(0.73)

$-0.457 \quad-0.426$

0.501

$-0.691$

$0.292-0.036$

\section{Civil Service Corruption}

High scores indicate bureaucrats have

"autonomy" and the "strength and

expertise to govern"

\begin{tabular}{lllllllll}
-0.663 & -0.685 & -0.722 & -0.630 & -2.64 & -2.59 & -2.83 & -1.82 & 27 \\
$(0.00)$ & $(0.00)$ & $(0.00)$ & $(0.00)$ & $(0.01)$ & $(0.02)$ & $(0.00)$ & $(0.07)$ & \\
& & & & & & & & \\
0.521 & 0.501 & 0.578 & 0.424 & 0.195 & 0.160 & 0.218 & 0.080 & 27 \\
$(0.01)$ & $(0.01)$ & $(0.00)$ & $(0.03)$ & $(0.12)$ & $(0.23)$ & $(0.06)$ & $(0.50)$ & \\
\hline
\end{tabular}

\section{Regulatory Barriers to Entry}

Estimated regulatory compliance cost of starting a new business, as \% of GDP

Numbers in parenthesis are probability levels for the null hypothesis of zero correlation or zero regression coefficient. Regressions are of the form rent-seeking measure $=a+b \times$ family control incidence $+c \times$ the logarithm of 1995 per capita GDP $+e$. 


\section{DAVIDSON INSTITUTE WORKING PAPER SERIES - Most Recent Papers}

The entire Working Paper Series may be downloaded free of charge at: www.wdi.bus.umich.edu

CURRENT AS OF 6/30/03

\begin{tabular}{|c|c|c|}
\hline Publication & Authors & Date \\
\hline No. 585: Family Control and the Rent-Seeking Society & $\begin{array}{l}\text { Randall Morck and Bernard } \\
\text { Yeung }\end{array}$ & June 2003 \\
\hline $\begin{array}{l}\text { No. 584: Wage Determination: Privatised, New Private and State } \\
\text { Owned Companies, Empirical Evidence from Panel Data }\end{array}$ & $\begin{array}{l}\text { Tomasz Mickiewicz and Kate } \\
\text { Bishop }\end{array}$ & June 2003 \\
\hline No. 583: An Investigation of Firm-Level R\&D Capabilities in East Asia & $\begin{array}{l}\text { Gary H. Jefferson and Zhong } \\
\text { Kaifeng }\end{array}$ & June 2003 \\
\hline $\begin{array}{l}\text { No. 582: R\&D and Technology Transfer: Firm Level Evidence From } \\
\text { Chinese Industry }\end{array}$ & $\begin{array}{l}\text { Albert G.Z. Hu, Gary H. } \\
\text { Jefferson, Guan Xiaojing and } \\
\text { Qian Jinchang }\end{array}$ & June 2003 \\
\hline $\begin{array}{l}\text { No. 581: Credit Market Disequilibrium in Poland: Can We Find } \\
\text { What We Expect? Non-Stationarity and the "Min" } \\
\text { Condition }\end{array}$ & $\begin{array}{l}\text { Christophe Hurlin†and Rafal } \\
\text { Kierzenkowski }\end{array}$ & June 2003 \\
\hline $\begin{array}{l}\text { No. 580: Does it Take a Lula to go to Davos? } \\
\text { A Brief Overview of Brazilian Reforms, 1980-2000 }\end{array}$ & $\begin{array}{l}\text { Nauro F. Campos, Armando } \\
\text { Castellar Pinheiro, Fabio } \\
\text { Giambiagi and Maurício M. } \\
\text { Moreira }\end{array}$ & June 2003 \\
\hline $\begin{array}{l}\text { No. 579: Ceaseless Toil? Health and Labor Supply of the Elderly in } \\
\text { Rural China }\end{array}$ & $\begin{array}{l}\text { Dwayne Benjamin, Loren Brandt } \\
\text { and Jia-Zhueng Fan }\end{array}$ & June 2003 \\
\hline $\begin{array}{l}\text { No. 578: Shadow Economy, Rent-Seeking Activities and the Perils of } \\
\text { Reinforcement of the Rule of Law }\end{array}$ & Ekaterina Vostroknutova & June 2003 \\
\hline $\begin{array}{l}\text { No. 577: No Pain, No Gain: Market Reform, Unemployment, and } \\
\text { Politics in Bulgaria }\end{array}$ & Neven Valev & June 2003 \\
\hline $\begin{array}{l}\text { No. 576: Power Analysis of the Nice Treaty On the Future of European } \\
\text { Integration }\end{array}$ & Yener Kandogan & June 2003 \\
\hline $\begin{array}{l}\text { No. 575: Democracy's Spread: Elections and Sovereign Debt in } \\
\text { Developing Countries }\end{array}$ & $\begin{array}{l}\text { Steven A. Block, Burkhard N. } \\
\text { Schrage, and Paul M. Vaaler }\end{array}$ & June 2003 \\
\hline $\begin{array}{l}\text { No. 574: Reintroducing Intergenerational Equilibrium: Key Concepts } \\
\text { Behind the New Polish Pension System }\end{array}$ & Marek Góra & June 2003 \\
\hline $\begin{array}{l}\text { No. 573: Why Does FDI Go Where It Goes? New Evidence From the } \\
\text { Transition Economies }\end{array}$ & $\begin{array}{l}\text { Yuko Kinoshita and Nauro F. } \\
\text { Campos }\end{array}$ & June 2003 \\
\hline $\begin{array}{l}\text { No. 572: Private Savings in Transition Economies: Are There Terms of } \\
\text { Trade Shocks? }\end{array}$ & Abdur R. Chowdhury & May 2003 \\
\hline $\begin{array}{l}\text { No. 571: On the long-run determinants of real exchange rates for } \\
\text { developing countries: Evidence from Africa, Latin America and Asia }\end{array}$ & Imed Drine and Christophe Rault & May 2003 \\
\hline $\begin{array}{l}\text { No. 570: A re-examination of the Purchasing Power Parity using non- } \\
\text { stationary dynamic panel methods: a comparative approach for } \\
\text { developing and developed countries }\end{array}$ & Imed Drine and Christophe Rault & May 2003 \\
\hline $\begin{array}{l}\text { No. 569: How Important is Ownership in a Market with Level Playing } \\
\text { Field? The Indian Banking Sector Revisited }\end{array}$ & $\begin{array}{l}\text { Sumon Kumar Bhaumik and } \\
\text { Ralitza Dimova }\end{array}$ & May 2003 \\
\hline $\begin{array}{l}\text { No. 568: On Types of Trade, Adjustment of Labor and Welfare Gains } \\
\text { During Asymmetric Liberalizations }\end{array}$ & Yener Kandogan & May 2003 \\
\hline $\begin{array}{l}\text { No. 567: Technological Progress Through Trade Liberalization in } \\
\text { Transition Countries }\end{array}$ & Yener Kandogan & May 2003 \\
\hline $\begin{array}{l}\text { No. 566: Intra-industry Trade of Transition Countries: Trends and } \\
\text { Determinants }\end{array}$ & Yener Kandogan & May 2003 \\
\hline $\begin{array}{l}\text { No. 565: Local Protectionism and Regional Specialization: Evidence } \\
\text { from China's Industries }\end{array}$ & $\begin{array}{l}\text { Chong-En Bai, Yingjuan Du, } \\
\text { Zhigang Tao, Sarah Y. Tong }\end{array}$ & May 2003 \\
\hline No. 564: Corporate Governance and Market Valuation in China & $\begin{array}{l}\text { Chong-En Bai, Qiao Liu, Joe Lu, } \\
\text { Frank M. Song, and Junxi Zhang }\end{array}$ & May 2003 \\
\hline $\begin{array}{l}\text { No. 563: Revenue Sharing and Control Rights in Team Production: } \\
\text { Theories and Evidence From Joint Ventures }\end{array}$ & $\begin{array}{l}\text { Chong-En Bai, Zhigang Tao, and } \\
\text { Changqi Wu }\end{array}$ & May 2003 \\
\hline $\begin{array}{l}\text { No. 562: Financial Dependence, Stock Market Liberalizations and } \\
\text { Growth }\end{array}$ & Nandini Gupta and Kathy Yuan & May 2003 \\
\hline
\end{tabular}

